\title{
Plant Growth-Promoting Activity of Endophytic Fungi Isolated from the Roots of Native Plants in Dokdo Islands
}

Young-Hyun You', Hyeokjun Yoon ${ }^{1}$, Ju-Ri Woo', Yeonggyo Seo', Miae Kim', Yeon-Sik Choo ${ }^{2}$ and Jong-Guk Kim ${ }^{1} \star$

\author{
${ }^{1}$ Department of Life Sciences and Biotechnology, Kyungpook National University, Daegu 702-701, Korea \\ ${ }^{2}$ Department of Biology, College of National Sciences, Kyungpook National University, Daegu 702-701, Korea
}

Received October 19, 2011 /Revised November 10, 2011 / Accepted November 11, 2011

\begin{abstract}
Endophytic fungal strains were isolated from the roots of six species plants in the Dokdo islands. Native plant samples, such as Artemisia japonica, Chenopodium album and Solanum nigrum were isolated from Dongdo, and those such as Cyrtomium falcatum, Dianthus longicalyx and Tetragonia tetragonoides were isolated from Seodo. In total, thirty two fungal strains were isolated from these native plants. To identify the fungal strains, polymerase chain reaction (PCR) amplification of internal transcribed spacer (ITS: containing ITS1, 5.8s and ITS2 region) regions was done with universal primers ITS1 and ITS4. Endophytic fungi of four species were isolated from $A$. japanica, eight species from $C$. album, three species from $S$. nigrum, three species from $C$. falcatum, three species from $D$. longicalyx and eleven species from $T$. tetragonoides. Culture filtrates $(\mathrm{CF})$ of isolated endophytic fungi were used to treatwaito-c rice seedlings to test plant growth-promoting activity. As a result of bioassay, Ca-5-2-2 strain isolated from $C$. album expressed highest plant growth-promotion activity. Of all the endophytic fungi isolated, Penicillium sp., Fusarium sp. and Aspergillus sp. were the most abundantly distributed fungal strains in the six plants used in this study.
\end{abstract}

Key words : Dokdo islands, diversity, endophytic fungi, plant growth-promotion

\section{서 론}

독도는 해양성 화산도로 북서태평양 연해인 동해의 남부와 울릉분지 북쪽 경계에 위치(E $\left.131^{\circ} 52^{\prime} 07^{\prime \prime} / \mathrm{N} 37^{\circ} 14^{\prime} 12^{\prime \prime}\right)$ 하 고 있다. 독도 근해는 한류와 난류가 만나 완대류를 형성하고 있으며, 연평균 $12^{\circ} \mathrm{C}$ 의 기온을 나타내고 눈과 비가 오는 날이 많으며, 강한 바람의 영향과 급경사 지역이 대부분을 차지하 고 있어서 식물이 서식하기에는 악조건을 가지고 있다. 독도 는 동도와 서도로 구분되고, 89 개의 작은 부속 섬들로 이루어 져 있으며, $40^{\circ}$ 이상의 급사면이 $65.4 \%$ 를 이루고 있어 급경사 가 많은 지역이다[2,5]. 토양환경은 화산활동에 의해서 형성되 었고, 염분함량이 높고 매우 건조하며 광조건 및 유기영양분 이 상당히 부족하다[16,18]. 그리고 독도는 온난 다습한 기후이 며, 한반도와는 떨어져있어서 다른 환경조건으로 인하여 특수 한 식물상 및 식물군락을 형성하고 있다. 독도는 고유한 생태 적 및 경관적 가치에 따라 r문화재보호법」에 의거하여 천연기 념물로 지정되어 있다. 독도의 식물상에 대한 연구는 1952년 부터 수행되어오고 있으며[2,6,14-18], 48종의 식물이 자생하고 있는 것으로 알려져 있다[2,6,12-15]. 그리고 독도의 미생물에 대한 연구는 식물근권세균(PGPR) 및 새로운 미생물종이 발견
될 가능성이 상당히 높은 지역으로 인식되고 있다[2,6,21].

식물생육을 위해서는 내생균류가 중요한 역할을 담당하고 있음이 알려져 있으며, 내생균류중에는 식물의 생장에 관여하 는 식물생장호르몬인 gibberellins (GA), ABA abscisic acid (ABA), Auxin (IAA) 등을 생산하는 균주에 대한 연구가 알려 져 있다[8,9,11]. 그리고 식물생장호르몬 생산균류를 식물에 이 용한 연구도 증가 하고 있다 $[1,4,5,10]$. 그러나 현재 독도에서는 식물뿌리 내생균류를 포함한 균류에 관한 연구는 많이 알려져 있지 않지만, 소수 연구자에 의해서 수행되고 있다[22].

본 연구에서는 동도에 자생하고 있는 갯제비쑥 (Artemisia japonica)과 명아주(Chenopodium album) 그리고 까마중 (Solanum nigrum), 서도에 서식하고 있는 도깨비쇠고비 (Cyrtomium falcatum)와 술패랭이(Dianthus longicalyx) 그리고 번행초(Tetragonia tetragonoides)의 뿌리내부에서 공생 및 상호 작용하고 있는 내생균을 분리하고, rDNA-ITS (ITS1, 5.8S, ITS2) 영역을 동정하였으며[22], 독도 자생식물의 뿌리로부터 분리된 내생균들이 가지는 식물생장촉진활성을 검정하기 위 하여 bioassay를 수행하였다. 그리고 본 연구에서 분리된 내생 균의 계통수 및 다양성을 분석하였다 $[7,9,10,14]$.

\section{*Corresponding author}

Tel : +82-53-950-537, Fax : +82-53-955-5379

E-mail : kimjg@knu.ac.kr 


\section{재료 및 방법}

\section{실험 균주 및 식물재료}

본 연구에서 사용된 식물시료는 동도(Dongdo)에서 채취한 갯제비쑥과 명아주 및 까마중을 사용하였고, 서도(Seodo)에서 도깨비쇠고비와 술패랭이 그리고 번행초를 채취하여 하였다 (Table 1). 미생물시료는 동도와 서도에 자생하는 식물의 뿌리 로부터 내생균들을 분리하여 사용하였고, 식물생장촉진검정 을 위하여 대조구(positive control)로 한국미생물보존센터 (KCCM)로부터 분양받은 Gibberella fujikuroi (KCCM 12329) 균주를 사용하였으며 [8], 식물생장촉진활성 검정을 위하여 식 물시료는 난장이벼(waito-c)를 사용하였다[11].

\section{내생균의 분리 및 배양조건}

독도에서 채취한 식물 시료의 토양을 모두 제거하고, 계면 활성제인 Tween 80 을 첨가하고 10 분간 처리한 후에 증류수로 세척하였다. 그리고 과염소산(Perchloric acid) $1 \%$ 에 10 분간 2회 처리한 후, 증류수로 세척하였으며 3 4 cm크기로 절단하 여 수분을 제거하였다. 그리고 내생균들을 분리하기 위하여 스트렙토마이신(streptomycin) $80 \mathrm{ppm}$ 이 포함된 Hagem minimal medium을 사용하여 $25^{\circ} \mathrm{C}$ 에서 배양하였다 [19,20]. 그 리고 potato dextrose agar (PDA) plate에 계대배양 (subculture)하여 순수 분리하였다 [7,10,22].

독도 자생식물뿌리에서 순수 분리한 내생균들을 배양하기 위하여 Czapek's liquid medium에 접종하여 $180 \mathrm{rpm}$ 으로 $25^{\circ} \mathrm{C}$ 조건으로 7일간 진탕배양(shake culture)하였고 [8], filter paper (Whatman)를 사용하여 균류배양액을 여과하여 식물생 장촉진활성검정 시료로 준비하였다 $[3,8,9]$. 그리고 내생균의 균체(mycobiont)와 배양여액(CF: culture filtrate)은 균류의 동 정과 식물생장촉진활성검정을 위하여 5 7일 동안 동결건조를 수행하였고, 배양여액은 30 배 농축하여 사용하였다.

\section{Genomic DNA의 추출과 PCR 조건}

동결건조를 수행한 내생균들은 DNeasy Plant mini kit (QIAgen)를 이용하여 genomic DNA를 추출하였다[10]. 추출 된 genomic DNA는 universal primer인 ITS1 (5'-TCC GTA
GGT GAA CCT GCG G-3')과 ITS4 (5'-GGA AGT AAA AGT CGT AAC AAG G-3')를 사용하여 rDNA-ITS영역을 증폭하였 다[8]. Polymerase chain reaction (PCR) 조건은 최종농도 10 $\mathrm{mM}$ Tris- $\mathrm{HCl}$ (pH 8.5), $40 \mathrm{mM} \mathrm{KCl}, 1.5 \mathrm{mM} \mathrm{MgCl}, 200 \mathrm{nM}$ $\mathrm{dNTPs}$ 이고, 10 pmol의 primer와 0.1 unit의 Ex-Taq DNA polymerase (Takara)를 사용하였다. 반응조건은 predenaturation $\left(95^{\circ} \mathrm{C}, 2 \mathrm{~min}\right)$, denaturation $\left(95^{\circ} \mathrm{C}, 30 \mathrm{sec}\right)$, annealing $\left(54.5^{\circ} \mathrm{C}\right.$, $1 \mathrm{~min})$, extension $\left(72^{\circ} \mathrm{C}, 1 \mathrm{~min}\right)$, total cycles $(35 \mathrm{cycles})$, final extension $\left(72^{\circ} \mathrm{C}, 7 \mathrm{~min}\right)$ 으로 수행하여 증폭된 $\mathrm{PCR}$ 산물은 $1.5 \%$ Agarose gel에서 전기영동 후, Ethidium bromide (EtBr) 을 사용하여 10 분 염색한 후, UV transilluminator에서 전기영 동밴드를 확인 하였다[14,22]. 그리고 증폭된 전기영동 단편들 은 QIAquick PCR purification kit (Qiagen Inc., Germany)를 사용하여 정제하였고, ABI PRISM BigDye Terminator Cycle Sequencing Kit (PE Biosystems, Foster City, CA, USA)를 사 용하였으며, 생산된 DNA 단편들은 $\mathrm{ABI} 310 \mathrm{DNA}$ sequencer (Perkin Elmer, Foster City, CA, USA)를 사용하여 염기서열을 결정하였다[8,16].

\section{내생균의 계통분석}

그리고 ClustalX 프로그램으로 다중정렬을 수행한 후, Lasergene 7과 BioEdit 프로그램을 사용하여 염기서열을 정리 하였다. 그리고 분석된 내생균의 계통분석은 MEGA 4.1프로 그램 Neighbor-Joining (NJ: 1000 bootstrap replicates) 방법으 로 수행하여 분석하였다[11,14]. 내생균들의 분자적인 동정을 위하여 rDNA-ITS 영역의 염기서열을 blastn 프로그램을 이용 하여 분석하였다.

\section{식물생장촉진활성 검정}

식물생장촉진활성을 검정하기 위하여 스포탁을 24시간 처 리하여 난장이벼의 볍씨를 소독하였고, uniconazol $20 \mathrm{ppm}$ 을 처리하여 난장이벼의 지베렐린 생합성억제를 유도하였다. 그 리고 발아된 난장이벼를 water agar $(0.6 \%)$ 에 파종하여 배양하 였다. 난장이벼 유묘의 이엽기 부분에 내생균의 농축배양여액 을 엽액에 $10 \mu \mathrm{l}$ 처리한 후, 7일간 생장촉진활성을 검정하였다 $[8,9]$.

Table 1. Geographic coordinates of the six plants in Dokdo islands

\begin{tabular}{|c|c|c|}
\hline Plant samples ${ }^{\mathrm{a}}$ & Geographic coordinates ${ }^{b}$ & Local $^{\mathrm{c}}$ \\
\hline Artemisia japonica & E $131^{\circ} 52^{\prime} 10^{\prime \prime} / \mathrm{N} 37^{\circ} 14^{\prime} 29^{\prime \prime}$ & Dongdo \\
\hline Chenopodium album & E $131^{\circ} 52^{\prime} 11^{\prime \prime} / \mathrm{N} 37^{\circ} 14^{\prime} 25^{\prime \prime}$ & Dongdo \\
\hline Solanum nigrum & E $131^{\circ} 52^{\prime} 07^{\prime \prime} /$ N $37^{\circ} 14^{\prime} 24^{\prime \prime}$ & Dongdo \\
\hline Cyrtomium falcatum & E $131^{\circ} 51^{\prime} 4^{\prime \prime} / \mathrm{N} 37^{\circ} 14^{\prime} 33^{\prime \prime}$ & Seodo \\
\hline Dianthus longicalyx & E $131^{\circ} 51^{\prime} 4^{\prime \prime} / \mathrm{N} 37^{\circ} 14^{\prime} 34^{\prime \prime}$ & Seodo \\
\hline Tetragonia tetragonoides & E $131^{\circ} 51^{\prime} 53^{\prime \prime} / \mathrm{N} 37^{\circ} 14^{\prime} 31^{\prime \prime}$ & Seodo \\
\hline
\end{tabular}

${ }^{a}$ Scientific name of plants grow naturally in Dokdo islands.

${ }^{\mathrm{b}}$ Geographic coordinates of six plants grow naturally in Dokdo islands.

${ }^{\mathrm{c}}$ The grow naturally region of six plants in Dokdo islands. 


\section{결과 및 고찰}

내생균의 동정 및 계통분석

독도 자생식물 6 종으로부터 형태적으로 다른 내생균를 선별
하였다. 분리된 내생균은 갯제비쑥으로부터 4 종, 명아주로부터 8 종, 까마중으로부터 3 종, 도깨비쇠고비로부터 3종, 술패랭이로 부터 3종 그리고 번행초로부터 11종으로 모두 32종의 내생균들 을 선별하여 동정하였다(Table 2). 내생균들의 동정 결과, 동도

Table 2. Occurrence of endophytic fungi isolated from the roots of plants growing naturally in Dokdo islands (unit: species)

\begin{tabular}{lcccccc}
\hline & \multicolumn{5}{c}{ Plant samples } \\
\cline { 2 - 6 } Fungal strain & $\begin{array}{c}\text { Artemisia } \\
\text { japonica }\end{array}$ & Chenopodium album & $\begin{array}{c}\text { Solanum } \\
\text { nigrum }\end{array}$ & $\begin{array}{c}\text { Cyrtomium } \\
\text { falcatum }\end{array}$ & $\begin{array}{c}\text { Dianthus } \\
\text { longicalyx }\end{array}$ & $\begin{array}{c}\text { Tetragonia } \\
\text { tetragonoides }\end{array}$ \\
\hline Penicillium sp. & 3 & 3 & 1 & 2 & 3 & 6 \\
Fusarium sp. & 1 & 4 & & & 1 \\
Sordariomycetes sp. & & 1 & 2 & 1 & 2 \\
Aspergillus sp. & & & & & 1 \\
Mucor sp. & & & & 1 \\
Exserohilum sp. & & & & & 1 \\
Acremonium sp. & & & & & \\
\hline
\end{tabular}

Endophytic fungi of 32 kinds isolated from roots of six plants are arranged above the table. The penicillium sp. was isolated from roots of six plants. T. tetragonoides had various kinds and the most number of fungal strains.

Table 3. The identification of endophytic fungi isolated in this study

\begin{tabular}{|c|c|c|c|c|c|}
\hline $\begin{array}{l}\text { Sampling } \\
\text { location }\end{array}$ & Host plant & $\begin{array}{l}\text { Fungal } \\
\text { isolates }\end{array}$ & $\begin{array}{l}\text { Closest relative based on } \\
\text { sequence homology }\end{array}$ & Similarity & $\begin{array}{l}\text { Accession } \\
\text { No. }\end{array}$ \\
\hline \multirow{15}{*}{ Dongdo } & \multirow{4}{*}{$\begin{array}{l}\text { Artemisia } \\
\text { japonica }\end{array}$} & Aj-2-3 & Penicillium sp. (GU446645) & 100 & JN859828 \\
\hline & & $\mathrm{Aj}-4-3$ & Penicillium sp. (AB558283) & 100 & JN859829 \\
\hline & & Aj-5-1-2 & Fusarium oxysporum (FR750926) & 100 & JN859830 \\
\hline & & Aj-6-1 & Penicillium thomii (FR670338) & 100 & JN859831 \\
\hline & \multirow{8}{*}{$\begin{array}{c}\text { Chenopodium } \\
\text { album }\end{array}$} & Ca-3-1 & Penicillium simplicissimum (GU981584) & 99 & JN859832 \\
\hline & & Ca-5-2 & Fusarium sp. (HQ662681) & 100 & JN859833 \\
\hline & & Ca-5-2-1 & Sordariomycetes sp. (GU944852) & 100 & JN859834 \\
\hline & & Ca-5-2-2 & Fusarium oxysporum (HQ271449) & 99 & JN859835 \\
\hline & & Ca-5-2-3 & Penicillium decaturense (AF125946) & 99 & JN859836 \\
\hline & & Ca-6-1 & Penicillium thomii (FR670339) & 100 & JN859837 \\
\hline & & $\mathrm{Ca}-6-3$ & Fusarium oxysporum (JN222394) & 99 & JN859838 \\
\hline & & Ca-6-3-1 & Fusarium oxysporum (HQ451893) & 100 & JN859839 \\
\hline & \multirow{3}{*}{$\begin{array}{l}\text { Solanum } \\
\text { nigrum }\end{array}$} & Sn-7-2 & Aspergillus niger (JF838357) & 100 & JN859840 \\
\hline & & Sn-9-2 & Aspergillus tubingensis (JF436888) & 100 & JN859841 \\
\hline & & Sn-12-1 & Penicillium simplicissimum (GU981587) & 99 & JN859842 \\
\hline \multirow{17}{*}{ Seodo } & \multirow{3}{*}{$\begin{array}{l}\text { Cyrtomium } \\
\text { falcatum }\end{array}$} & Cf-3-1 & Penicillium decaturense (HM469399) & 99 & JN859843 \\
\hline & & Cf-6-1 & Penicillium sp. (FJ379821) & 99 & JN859844 \\
\hline & & Cf-7-1 & Mucor circinelloides (HQ285608) & 99 & JN859845 \\
\hline & \multirow{3}{*}{$\begin{array}{l}\text { Dianthus } \\
\text { longicalyx }\end{array}$} & Dl-3-1 & Penicillium funiculosum (HM469427) & 100 & JN859846 \\
\hline & & Dl-3-2 & Penicillium adametzii (AF034459) & 100 & JN859847 \\
\hline & & D1-3-3 & Penicillium sp. (HQ631007) & 100 & JN859848 \\
\hline & \multirow{11}{*}{$\begin{array}{l}\text { Tetragonia } \\
\text { tetragonoides }\end{array}$} & Tt-1-2 & Fusarium oxysporum (FR750926) & 99 & JN859849 \\
\hline & & $\mathrm{Tt}-2-1$ & Penicillium canescens (JF311958) & 100 & JN859850 \\
\hline & & $\mathrm{Tt}-2-3$ & Aspergillus terreus (JN129183) & 99 & JN859851 \\
\hline & & $\mathrm{Tt}-3-1$ & Aspergillus tubingensis (JF436887) & 98 & JN859852 \\
\hline & & $\mathrm{Tt}-3-4$ & Exserohilum rostratum (GU966507) & 100 & JN859853 \\
\hline & & Tt-4-1-1 & Penicillium thomii (FR670338) & 100 & JN859854 \\
\hline & & $\mathrm{Tt}-4-5$ & Penicillium citrinum (JF266706) & 100 & JN859855 \\
\hline & & Tt-4-6 & Acremonium cellulolyticus (GU479898) & 99 & JN859856 \\
\hline & & Tt-5-1 & Penicillium janthinellum (HQ839782) & 99 & JN859857 \\
\hline & & $\mathrm{Tt}-6-3$ & Penicillium simplicissimum (HQ607866) & 99 & JN859858 \\
\hline & & $\mathrm{Tt}-6-4$ & Penicillium spinulosum (HQ608158) & 100 & JN859859 \\
\hline
\end{tabular}


Table 4. Screening for plant growth-promotion of Waito-c rice seedlings with CFs of endophytic fungi isolated from native plants in Dokdo islands

\begin{tabular}{|c|c|c|c|c|c|}
\hline $\begin{array}{l}\text { Fungal } \\
\text { isolates }\end{array}$ & SL & PL & $\begin{array}{l}\text { Fungal } \\
\text { isolates }\end{array}$ & SL & PL \\
\hline D. water* & $7.07 \pm 0.21^{\mathrm{ijk} / m n}$ & $13.77 \pm 0.25^{1}$ & Cf-3-1 & $6.07 \pm 0.42^{\circ}$ & $14.87 \pm 0.47^{\mathrm{k}}$ \\
\hline G. fujikuror $^{* *}$ & $11.43 \pm 0.25^{\mathrm{a}}$ & $21.30 \pm 0.61^{\mathrm{a}}$ & Cf-6-1 & $7.97 \pm 0.32^{\text {efghi }}$ & $16.97 \pm 0.71^{\text {bddefgh }}$ \\
\hline $\mathrm{Aj}-2-3$ & $6.80 \pm 0.30^{\operatorname{lmno}}$ & $15.33 \pm 0.60^{\mathrm{ijk}}$ & Cf-7-1 & $7.60 \pm 0.20^{\text {ghijklm }}$ & $17.27 \pm 1.05^{\mathrm{bcd}}$ \\
\hline $\mathrm{Aj}-4-3$ & $7.53 \pm 0.35^{\text {ghijklm }}$ & $15.83 \pm 0.61^{\mathrm{hijk}}$ & Dl-3-1 & $8.80 \pm 0.75^{\text {bcde }}$ & $16.43 \pm 0.51^{\text {defghi }}$ \\
\hline Aj-5-1-2 & $7.00 \pm 0.56^{\mathrm{klmn}}$ & $15.23 \pm 0.45^{\mathrm{jk}}$ & Dl-3-2 & $8.63 \pm 0.60^{\text {cdef }}$ & $16.40 \pm 0.79^{\operatorname{defghi}}$ \\
\hline Aj-6-1 & $7.70 \pm 0.56^{\text {ghijkl }}$ & $16.07 \pm 0.32^{\text {fghij }}$ & Dl-3-3 & $7.60 \pm 0.44^{\text {ghijklm }}$ & $17.63 \pm 0.49^{\mathrm{bc}}$ \\
\hline Ca-3-1 & $6.37 \pm 0.60^{\text {no }}$ & $13.27 \pm 0.68^{\mathrm{lm}}$ & Tt-1-2 & $7.00 \pm 0.46^{\mathrm{klmn}}$ & $14.97 \pm 0.42^{\mathrm{jk}}$ \\
\hline Сa-5-2 & $9.37 \pm 0.42^{\mathrm{bc}}$ & $17.17 \pm 1.07^{\text {bcdef }}$ & $\mathrm{Tt}-2-1$ & $6.97 \pm 0.20^{\mathrm{klmn}}$ & $15.13 \pm 0.31^{\mathrm{jk}}$ \\
\hline Ca-5-2-1 & $7.03 \pm 0.32^{\mathrm{jklmn}}$ & $12.40 \pm 0.80^{\mathrm{m}}$ & $\mathrm{Tt}-2-3$ & $7.60 \pm 0.44^{\text {ghijklm }}$ & $15.90 \pm 0.36^{\text {ghijk }}$ \\
\hline Ca-5-2-2 & $11.50 \pm 0.36^{\mathrm{a}}$ & $21.73 \pm 0.57^{\mathrm{a}}$ & Tt-3-1 & $6.77 \pm 0.31^{1 \mathrm{mno}}$ & $15.33 \pm 0.55^{\mathrm{ijk}}$ \\
\hline Ca-5-2-3 & $9.50 \pm 0.50^{\mathrm{bc}}$ & $16.10 \pm 0.46^{\text {efghij }}$ & $\mathrm{Tt}-3-4$ & $7.57 \pm 0.50^{\text {ghijklm }}$ & $15.90 \pm 0.70^{\text {ghijk }}$ \\
\hline Ca-6-1 & $8.73 \pm 0.25^{\text {bcde }}$ & $17.23 \pm 0.75^{\text {bcde }}$ & Tt-4-1-1 & $8.13 \pm 0.45^{\operatorname{defg}}$ & $16.83 \pm 0.35^{\text {cdefgh }}$ \\
\hline Ca-6-3 & $9.17 \pm 0.15^{\mathrm{bc}}$ & $15.37 \pm 0.55^{\mathrm{ijk}}$ & Tt-4-5 & $7.80 \pm 0.62^{\text {fghijk }}$ & $16.80 \pm 0.70^{\text {cdefgh }}$ \\
\hline Ca-6-3-1 & $9.60 \pm 0.40^{\mathrm{b}}$ & $16.10 \pm 0.46^{\text {efghij }}$ & $\mathrm{Tt}-4-6$ & $7.17 \pm 0.31^{\text {hijklmn }}$ & $16.47 \pm 0.06^{\text {defghi }}$ \\
\hline Sn-7-2 & $7.97 \pm 0.72^{\text {efghi }}$ & $14.93 \pm 0.51^{\mathrm{jk}}$ & Tt-5-1 & $8.00 \pm 0.36^{\text {efgh }}$ & $17.03 \pm 0.31^{\text {bcdefg }}$ \\
\hline Sn-9-2 & $7.53 \pm 0.85^{\text {ghijklm }}$ & $15.63 \pm 1.15^{\mathrm{ijk}}$ & $\mathrm{Tt}-6-3$ & $7.93 \pm 0.76^{\text {efghij }}$ & $17.50 \pm 0.30^{\mathrm{bcd}}$ \\
\hline Sn-12-1 & $8.87 \pm 0.32^{\text {bcd }}$ & $16.90 \pm 0.36^{\text {bcdefgh }}$ & $\mathrm{Tt}-6-4$ & $8.80 \pm 0.36^{\text {bcde }}$ & $18.03 \pm 0.29^{b}$ \\
\hline
\end{tabular}

The $10 \mathrm{ul}$ of lyophilized CFs were treated on the waito-c rice seedlings. The shoot and plant length of waito-c seedlings were measured after 7 days. According to DMRT, the different letters in a row indicate significant differences. All data $(p<0.05)$ are expressed as mean value \pm standard deviation.

SL: shoot length, PL: plant length

${ }^{*}$ Negative control (Distilled water)

** Positive control (Wild type G. fujikurol)

에 자생하는 갯제비쑥에서는 자낭균문(Ascomycota)에 속하는 Penicillium sp. (3종)와 Fusarium sp. (1종)이 분리되었고, 명아 주에서 자낭균문에 속하는 Penicillium sp. (3종), Fusarium sp. (4종) 그리고dariomycetes sp. (1종)이 분리되었으며, 까마중에 서는 Aspergillus sp. (2종)와 Penicillium sp. (1종)이 분리 및 동정 되었다. 서도에 자생하는 도깨비쇠고비에서는 자낭균문 에 속하는 Penicillium sp. (2종)과 그리고 털곰팡이 아문 (Mucoromycotina)에 속하는 Mucor sp. (1종)가 분리 되었고, 술패랭이에서는 자낭균문에 속하는 Penicilliumsp. (3종)이 분 리되었으며, 번행초에서는 자낭균문에 속하는 Penicillium sp. (6종), Fusarium sp. (1종), Aspergillus sp. (2종), Exserohilum sp. (1종) 그리고 Acremonium sp. (1종)가 분리 및 동정 되었다 (Table 3).

계통분석은 blastn방법을 이용하여 ClustalX 프로그램으로 32종의 내생균 염기서열을 다중정렬을 하였으며, Lasergene 과 BioEdit 프로그램을 사용하여 염기서열을 정리하였다. 그 리고 MEGA 4.1프로그램에서 NJ 방법은 계통수 분석에서 많 이 이용되고 있으며, 1000 bootstrap replicates방법으로 수행 을 하여 내생균에 대한 계통수를 작성하였다.

본 연구 결과로 얻어진 내생균에 대한 계통수는 2 가지 문 (phylum)으로 분류 할 수 있었으며, 동정된 내생균들은 자낭 균문과 털곰팡이 아문으로 분류되는 것이 확인 되었다(Fig.
1). 그리고 6종류의 독도자생식물 내생균에서 자낭균문에 속 하며 Trichocomaceae과에 속하는 Penicillium sp.와 Aspergillus $\mathrm{sp}$. 그리고 분류체계가 명확하지 않은 Hypocreales목에 속하 는Fusariumsp.가 많이 분포하고 있는 것을 확인 할 수 있었다.

\section{식물생장촉진활성 검정}

내생균에 의한 식물생장촉진활성 검정은 난장이벼 유묘의 지상부길이(shoot length)와 식물체길이(Plant length)로 확인 하였다. 그리고 통계처리는 실험으로부터 얻은 결과를 SPSS version 18.0을 이용하였고, 평균비교분석은 일원배치분산분 석(ANOVA: one-way analysis of variance)을 통하여 결과를 도출하였으며, 사후검정은 Duncan's multiple range test (DMRT)를 통하여 유의확률 $p<0.05$ 수준에서 분석되었다. 그 리고 내생균의 배양여액을 처리한 식물샘플은 Table 4에 a부 터 o까지 주석으로 차이점을 나타내었다. 그리고 식물생장촉 진활성 검정의 실험 결과는 평균 \pm 표준편차로 나타내어 분석 을 하였다.

본 연구에서는 내생균의 식물생장촉진활성을 검정하기 위 하여 bioassay를 3반복 수행하였으며, 명아주에서 분리된 Ca-5-2-2 [Fusarium oxysporum HQ271449]의 내생균이 waito-c의 생장을 가장 많이 촉진하는 것을 확인 할 수 있었다 (Table 4). 


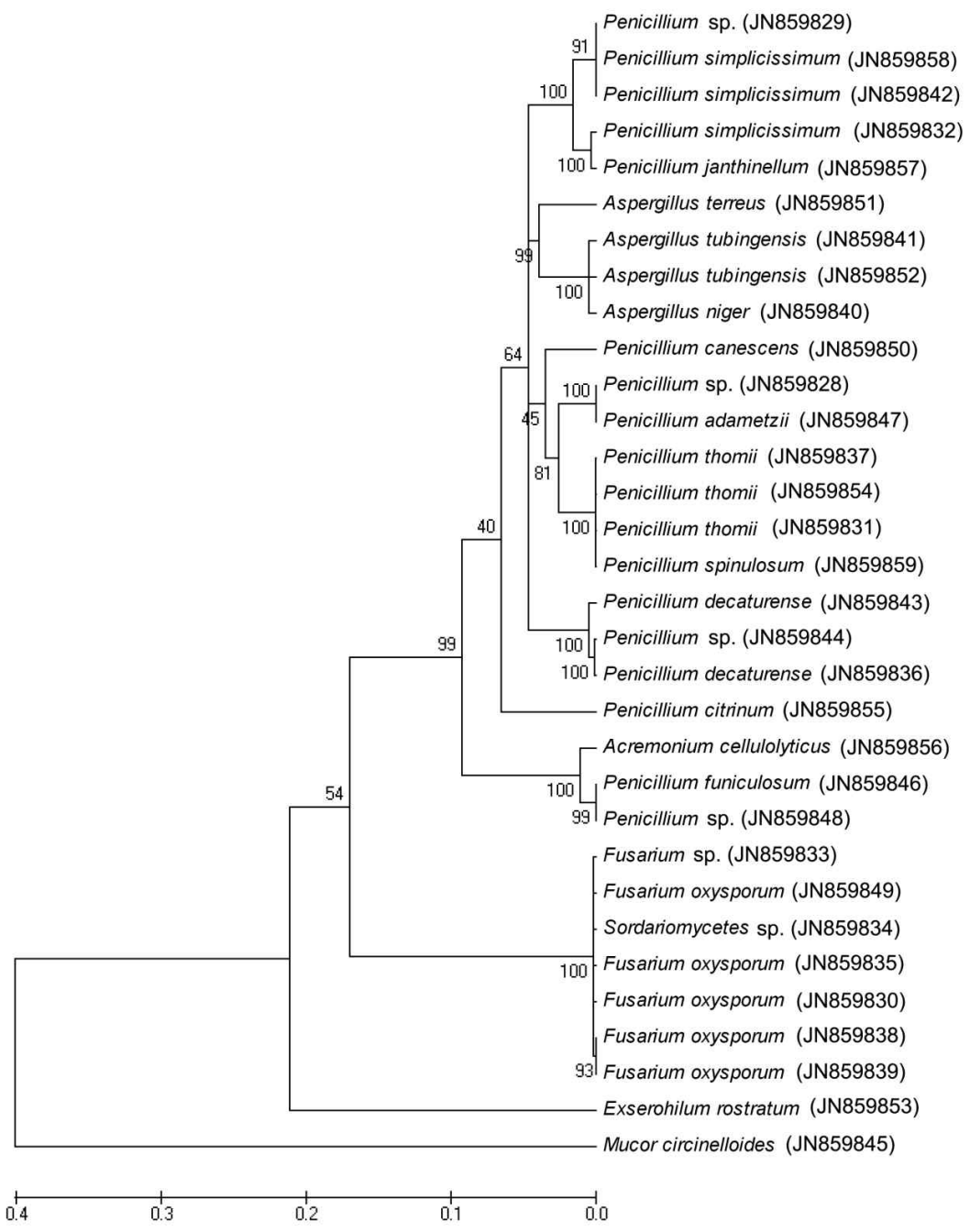

Fig. 1. Phylogenetic tree of endophytic fungi with rDNA-ITS sequences. The neighbour joining tree (1000 bootstrap replications) was constructed using 32 taxa. Phylogenetic analysis showed that all isolated endophytic fungal strains belong to the phylum Ascomycota or subphylum Mucoromycotina.

\section{감사의 글}

이 논문은 2009학년도 경북대학교 연구교수 연구비에 의하 여 연구되었으며, 연구비 지원에 감사 드립니다.

\section{References}

1. Clay, K. and J. Holah. 1999. Fungal endophyte symbiosis and plant diversity in successional fields. Science 285, 1742-1744.

2. Ham, M. S., Y. M. Park, H. R. Sung, M. Sumayo, C. M. Ryu, S. H. Park, and S. Y. Ghim. 2009. Characterization of rhizobacteria isolated from family Solanaceae plants in Dokdo island. Korean J. Microbiol. Biotechnol. 37, 110-117.

3. Hasan, H. A. 2002. Gibberellin and auxin-production by plant root-fungi and their biosynthesis under salinity-calcium interaction. Acta Microbiol. Immunol. Hung. 49, 105-118.

4. Hwang, J. S., H. Y. You, J. J. Bae, S. A. Khan, J. G. Kim, and Y. S. Choo. 2011. Effects of endophytic fungal secondary sporum Ca-5-2-2라고 명명하였다. 
metabolites on the growth and physiological response of Carex kobomugi Ohwi. J. Coastal Res. 27, 544-548.

5. Jeon, Y. G. 2005. The regional geomorphology of Dokdo (Volcanic Island). Korean J. Reg. Geol. 11, 19-28.

6. Kim, M. H., Y. J. Oh, C. S. Kim, M. S. Han, J. T. Lee, and Y. E. Na. 2007. The flora and vegetation distribution in Dokdo. Korean J. Environ. Agric. 26, 85-93.

7. Khan, S. A., M. Hamayun, S. O. Rim, I. J. Lee, J. C. Seu, Y. S. Choo, I. N. J, S. D. Kim, I. K. Lee, and J. G. Kim. 2008. Isolation of endophytic fungi capable of plant growth promotion from monocots inhibited in the coastal sand dunes of Korea. J. Life Sci. 18, 1355-1359.

8. Khan, S. A., M. Hamayun, H. Y. Kim, H. J. Yoon, I. J. Lee, and J. G. Kim. 2009. Gibberellin production and plant growth promotion by a newly isolated strain of Gliomastix murorum World J. Microbiol. Biotechnol. 25, 829-833.

9. Khan, S. A., M. Hamayun, H. J. Yoon, H. Y. Kim, S. J. Suh, S. K. Hwang, J. M. Kim, I. J. Lee, Y. S. Choo, U. H. Yoon, W. S. Kong, B. M. Lee, and J. G. Kim. 2008. Plant growth promotion and Penicillium citrinum BMC Microbiol. 8, 231.

10. Khan, S. A., M. Hamayun, H. Y. Kim, H. J. Yoon, J. C. Seo, Y. S. Choo, Y. J. Kil, J. K. Eo, and A. H. Eom. 2009. Molecular identification and diveristy of endophytic fungi isolated from Pinus densiflora in Boeun, Korea. Korean J. Mycol. 37, 130-133.

11. Khan, S. A., M. Hamayun, H. Y. Kim, H. J. Yoon, J. C. Seo, Y. S. Choo, I. J. Lee, S. D. Kim, I. K. Rhee, and J. G. Kim. 2009. A new strain of Arthrinium phaeospermum isolated from Carex kobomugi Ohwi is capable of gibberellin production. Biotechnol. Lett. 31, 283-287.

12. Lee, D. B. and S. U. Joo. 1958. Reinvestigation of the flora of the Dagelet Island. Humani. Sci. Nat. Sci. 3, 223-296.

13. Lee, D. H., S. H. Cho, and J. H. Pak. 2007. The analysis of vascular plant species composition in Dok-do island. Korean J. Plant Taxon. 37, 545-563.

14. Park, S. J., I. G. Song, S. J. Park, and D. O. Lim. 2010. The
Flora and Vegetation of Dokdo Island in Ulleung-gun, Gyeongsanbuk-do. Korean J. Env. Eco. 24, 264-278.

15. Research Institute for Ullengdo \& Dokdo Islands. 2008. pp. 166-221, The plant of Dokdo island. Nature of Dokdo island. Kyungpook National University Press. Daegu. Korea.

16. Seo, S. T., K. H. Kim, M. J. Kim, J. S. Hong, J. H. Park, and S. C. Shin. 2009. Diversity of fungal endophytes from Pinus koraiensis leaves in Korea. Korean J. Mycd. 37, 108-110.

17. Sun, B. Y., M. R. Sul, J. A. Im, C. H. Kim, and T. J. Kim. 2002. Evolution of endemic vascular plants of Ulleungdo and Dokdo in Korea - floristic and cytotaxonomic characteristics of vascular flora of Dokdo. Korean J. Plant Taxon. 32, 143-158.

18. Shin, H. T., S. J. Park, K. H. Kang, and J. H. Yoo. 2004. The establishment of conservation area and conservation strategy in Ulnung Island. Korean J. Environ. Eco. 18, 221-230.

19. Vazquez, M. M., S. Cesar, R. Azcon, and J. M. Barea. 2000. Interaction between arbuscular mycorrhizal fungi and other microbial inoculants (Azospirillum, Pseudomonas, Trichoderma) and their effects on microbial population and enzyme activities in the rhizosphere of maize plants. Appl. Soil Ecol. 15, 261-272.

20. Yamada, A., O. Takeo, D. Yosuke, and O. Masatake. 2001. Isolation of Tricholoma matsutake and T. bakamatsutake cultures from field-collected ectomycorrhizas. Mycoscience 42, 43-50.

21. Yoon, J. H., S. Y. Kang, M. H. Lee, and T. K. Oh. 2005. Virgibacillus dokdonensis sp. nov., isolated from a Korean island, Dokdo, located at the edge of the East Sea in Korean. Int. J. Syst. Evol. Microbiol. 51, 1079-1086.

22. You, Y. H., H. Yoon, G. S. Lee, J. R. Woo, J. H. Shin, I. J. Lee, S. O. Rim, Y. S. Choo, and J. G. Kim. 2011. Diversity and plant growth-promotion of endophytic fungi isolated from the roots of plants in Dokdo islands. J. Life Sci. 21, 992-996

\section{초록 : 독도 자생식물의 뿌리로부터 분리된 내생균의 식물생장촉진 활성}

유영현 ${ }^{1}$ - 윤혁준 ${ }^{1}$ 우주리 ${ }^{1} \cdot$ 서영교 ${ }^{1}$ 김미애 ${ }^{1}$ - 추연식 ${ }^{2}$ - 김종국 ${ }^{1}{ }^{*}$

(경북대학교 생명과학부, ${ }^{2}$ 경북대학교 생물학과)

독도에 자생하고 있는 6 종류의 식물뿌리로부터 내생균을 분리하였다. 동도에서 갯제비쑥, 명아주, 까마중과 서도에서 도깨비쇠고비, 술패랭이 그리고 번행초를 연구재료로 사용하였다. 총 32 종의 내생균을 분리하였고, universal primers ITS1과 ITS4를 사용하여 ITS 영역을 PCR로 증폭하여 동정하였다. 염기서열 분석결과, 6 종류 의 식물의 뿌리에서 모두 32종류의 다양한 내생균류를 분리 및 동정 할 수 있었다. 독도 자생식물인 갯제비쑥 4 종, 명아주 8 종, 까마중 3 종, 도깨비쇠고비 3 종, 술패랭이 3 종, 번행초 11 종의 내생균이 분리되었다. 내생균들의 배양여액은 식물생장촉진활성을 확인하기 위하여 난장이벼의 유묘에 처리되었다. 그 결과, 명아주에서 분리된 Ca-5-2-2 균주가 우수하게 식물생장촉진활성을 나타내었다. 그리고 독도에 자생하는 6종류의 식물에서 Penicillium sp.와 Fusarium sp. 그리고 Aspergillus sp.의 내생균이 가장 많이 존재함을 알 수 있었다. 